\title{
GLOBAL CONCENTRATION OF PULP EXPORTS
}

\author{
Luiz Moreira Coelho Junior ${ }^{1 *}$, Thaisa de Sousa Selvatti ${ }^{2}$, Filipe Vanderlei Alencar ${ }^{1}$, Edvaldo Pereira Santos \\ Júnior ${ }^{1}$, Luís Antônio Coimbra Borges ${ }^{2}$, José Luiz Pereira de Rezende ${ }^{2}$ \\ ${ }^{1}$ Universidade Federal da Paraíba, Centro de Energias Alternativas e Renováveis, João Pessoa, Paraíba, Brasil - luiz@cear.ufpb.br; \\ filipe.alencar@cear.ufpb.br; edvaldo.junior@cear.ufpb.br \\ ${ }^{2}$ Universidade Federal da Lavras, Departamento de Ciências Florestais, Lavras, Minas Gerais, Brasil - thaisaselvatti@gmail.com; \\ luis.borges@dcf.ufla.br; jlprezende@dcf.ufla.br
}

Received for publication: 30/08/2016-Accepted for publication: 08/06/2018

\begin{abstract}
This study analyzed the evolution and degree of the global concentration of pulp exports from 1961 to 2014. In order to measure and analyze the concentration, the following indicators were used: Concentration Ratio [CR(k)]; Herfindahl-Hirschman Index (HHI); Theil Entropy Index (E); Hall and Tideman Index (HTI); Comprehensive Concentration Index (CCI); and Gini Coefficient (G). We concluded that there was a tendency of growth in the global pulp exports during the analyzed period due to an increase in demand driven by population growth and to per capita consumption, enhancing the increase in the number of exporting countries. The $\mathrm{CR}(\mathrm{k})$ of the global pulp exporting countries showed that the four [CR(4)] and eight [CR(8)] largest countries present a high concentration, with an oligopolistic market structure and competitive advantage. About $100 \%$ of exports are dominated by the 20 largest countries [CR(20)]. The HHI, E, HTI, and CCI indicators showed that there is a concentration in global pulp exportation and presented a deconcentrating tendency. Despite the increase in the number of exporting countries, there was no significant reduction in the inequality of global pulp exports. According to the Gini Coefficient, the inequality was strong to absolute.

Keywords: Forest economy, market share, concentration indicators.
\end{abstract}

\section{Resumo}

Concentração mundial das exportações de celulose. Este trabalho analisou a evolução e o grau de concentração mundial das exportações de celulose no período de 1961 a 2014. Para mensurar e analisar a conjuntura e a concentração, foram utilizados: os indicadores: Razão de Concentração [CR(k)]; Índice de HerfindahlHirschman (HHI); Índice de Entropia de Theil; Índice de Hall e Tideman (HTI); Índice de Concentração Compreensiva (CCI); e Coeficiente de Gini (G). Os resultados permitiram concluir que, durante o período analisado, houve tendência de crescimento das exportações mundiais de celulose devido ao aumento da demanda, impulsionada pelo aumento populacional, e do consumo per capita, incentivando o aumento do número de países exportadores. O CR(k) dos países exportadores mundiais de celulose mostrou que os 4 maiores $[\mathrm{CR}(4)]$ e 8 maiores $[\mathrm{CR}(8)]$ países apresentaram concentração alta, com estrutura de mercado oligopolista com extremidade competitiva, e cerca de $100 \%$ das exportações estão sob domínio dos 20 maiores países [CR(20)]. Os indicadores HHI, E, HTI e CCI mostraram que há concentração nas exportações mundiais de celulose e apresentaram tendência de desconcentração. Apesar do aumento do número de países exportadores, não houve redução significativa na desigualdade das exportações mundiais de celulose. Segundo o Coeficiente de Gini, a desigualdade foi de forte a absoluta.

Palavras-chave: Economia florestal, market share, indicadores de concentração.

\section{INTRODUCTION}

Pulp is the main raw material for obtaining paper and can be classified according to its fiber size (short or long) and staining (bleached and unbleached). According to its specificities, pulp is used for different types of paper. Because of its high opacity and softness, short-fiber pulp is an input of printing and writing paper, sanitary paper (toilet paper and paper towels) and certain types of card stock paper. Long fiber pulp has higher strength, and is used in the process of manufacturing paper for packaging, press, corrugated cardboard and other types of card stock paper (INDÚSTRIA BRASILEIRA DE ÁRVORES - IBÁ, 2014).

Pulp commercialization is performed by domestic and foreign markets (market pulp), or can be used in paper production by the company that produces pulp (integrated pulp). Some producer countries such as the United States only export their surplus. In 2012, the United States produced about 50 million tons and only exported 5.6 million tons. In other cases, such as Brazil, the production is directed to the foreign market. In the year 2012, Brazil exported 8.9 million tons from a total production of 14.3 million tons (62\%)

FLORESTA, Curitiba, PR, v. 48, n. 4, p. 443-452, out/dez. 2018

Coelho Junior, L. M. et al.

ISSN eletrônico 1982-4688

DOI: $10.5380 /$ rf.v48i4.48334 
(FOOD AND AGRICULTURE ORGANIZATION OF THE UNITED NATIONS - FAO, 2013; MONTEBELLO; BACHA, 2013).

Over the past 50 years, population growth and increasing demand for pulp products have contributed to an increase in the number of exporting countries. In 1961, the world pulp market consisted of only 20 exporting countries, reaching a figure of US $\$ 342$ billion. In 2012, the number of exporting countries increased fivefold and reached 117 countries, exporting the amount of $\$ 34$ trillion. Canada, the United States and Brazil were respectively the largest pulp exporters in 2012. Together, these countries exported almost half of the entire amount exported that year (FAO, 2013).

In 2008, the pulp segment accounted for more than $82 \%$ of the world's exports of forest products. In addition, countries that have a significant share in pulp exports (such as Brazil) have been seeking strategies to retain their acquired competitive advantages, especially those coming from barriers to entry (COELHO JUNIOR et al., 2013). The pulp industry has an oligopolistic market structure due to the high degree of technological dominance, the specificity and irreversibility of invested capital, a large volume of initial fixed investments, the long maturity of the projects, as well as the inelastic supply and demand of pulp (RESENDE; BOFF, 2002; REZENDE et al. 2008).

In the broad sense, "industrial concentration" is understood as a procedure that focuses on increasing market control, and is one of the most respectable elements of competition among countries. There is an inverse relationship between concentration and competition, and as concentration increases, the degree of competition between countries decreases, thereby increasing the country's market power. Market power is shaped by the share that a given country has in the global production or sales of the forest industry. The measurement of concentration indices infers in the analysis of the pulp subsector structure and is evident in the competitiveness dimension of the exporting countries. The concentration indices synthesize a concept of multiple dimensions such as supply and demand, technological capacity, and cost structure, among others (POSSAS, 1999; COELHO JUNIOR et al., 2010).

The countries with the greatest territorial extension usually have comparative advantages in natural resources and tend to have greater share in the market of primary products. However, some countries and regions are better prepared to face challenges and seize opportunities, while others do not yet have the essential (institutional, legal and economic) conditions to sustainably manage forest resources (COELHO JUNIOR et al., 2013).

Concentration studies in the international market of the forestry sector have been carried out by Noce $e t$ al. (2007) for plywood, Noce et al. (2008) for particleboard, Coelho Junior et al. (2013) for forest products, Soares et al. (2014) for North American pulp imports, and Schettini et al. (2016) for the world market of wood pellets. In view of the importance of the pulp segment for the international forest products market, this paper analyzed the evolution and the degree of the global concentration of pulp exports in the period of 1961 to 2014.

\section{MATERIAL AND METHODS}

Data for measuring the concentration of world pulp exports were obtained from the FAO website for the period 1961 to 2014. The time series of total world pulp exports was used to perform an overall analysis. Also, the ten largest exporting countries were selected based on 2014 in trillions of US dollars (US $\$ 10^{9}$ ), the top ten in the ranking and the number of nations participating in exports for the years of 1961, 1964, 1969, 1974, 1979, 1984, 1989, 1994, 1999, 2004, 2009, and 2014.

In order to estimate the gains and losses in world pulp exports, the geometric growth rate (GGR) suggested by Cuenca and Dompieri (2017) and expressed in annual percentage (\% p.a.) was used according to Equation 1.

$$
G G R=1 / \Delta t \sqrt{\frac{V_{n}}{V_{0}}}-1 * 100
$$

In which: $V_{n}$ : pulp exports for the final year (2014); $V_{0}$ : pulp production for the initial year (1961); $\Delta t$ : time variation of consumption (expressed in years).

The indexes used in the study were suggested by Coelho Junior et al. (2013): Concentration Ratio, Herfindahl-Hirschman Index, Theil Entropy Index, and the Gini Coefficient. In addition to these, the Hall and Tideman Index and the Comprehensive Concentration Index were also used. 
The Concentration ratio $[C R(k)]$ was developed by Bain (1959) and can be applied to the study object, since it considers the participation of $\mathrm{k}$ (being $k=1,2, \ldots, \mathrm{n}$ ) as the largest pulp exporters in the world. Its algebraic form is expressed by Equation 2.

$$
C R(k)=\sum_{i=1}^{k} S i
$$

In which: $S i$ : market share of country $i$ (in percentage) in world pulp exports.

Traditionally, concentration ratios were calculated with four $[\mathrm{CR}(4)]$ and eight $[\mathrm{CR}(8)]$ and classified according to Table 1 . In this study, CR(4), CR(8) and CR(20) of the world's largest pulp exporters were measured to assist in the concentration analysis.

The Herfindahl-Hirschman Index (HHI) shows the relative weights of the squared participation share of each pulp exporting country. Thus, the countries that have the greatest share are given greater weight. The equation appropriate to the study object and suggested by Hirschman (1964) is presented below (Equation 3).

(3)

In which: $n$ : number of participating nations.

$$
H H I=\sum_{i=1}^{n} S_{i}^{2}
$$

The HHI parameters are between $1 / n$ (lower limit) and 1 . In the first situation all countries have the same size, while in the second the concentration is maximum.

Table 1. Classification of the concentration degree of the major exporting countries.

Tabela 1. Classificação do grau de concentração dos maiores países exportadores.

\begin{tabular}{lcc}
\hline Concentration degree & CR (4) & CR(8) \\
\hline Very high & $75 \%$ or more & $90 \%$ or more \\
High & $65 \%-75 \%$ & $85 \%-90 \%$ \\
Moderately high & $50 \%-65 \%$ & $70 \%-85 \%$ \\
Moderately low & $35 \%-50 \%$ & $45 \%-70 \%$ \\
Low & $35 \%$ or less & $45 \%$ or less \\
\hline
\end{tabular}

Source: Bain (1959).

As proposed by Resende (1994), the adjusted HHI (HHI') performs comparative analyzes when a variation in the number of countries occurs over time (Equation 4$)$.

$$
H H I^{\prime}=\frac{1}{n-1}(n H H I-1) ; n>1
$$

This index has a range between 0 and 1 and may be classified as: values of HHI' $<0.10$ indicate a competitive market; values of $0.10 \leq \mathrm{HHI}$ ' $<0.15$ indicate a non-concentrated market; values of $0.15 \leq \mathrm{HHI} \leq 0.25$ indicate moderate concentration; and values of HHI' $>0.25$ indicate a high concentration.

Resende and Boff (2002) indicated the use of Theil's Entropy Index (E) in industrial concentration analyzes. The E measures the inverse of the HHI, meaning the lower the index value the more concentrated the exports, according to the following equation (Equation 5).

In which: $\ln$ : natural logarithm.

$$
E=-\sum_{i=1}^{n} \operatorname{Si} \ln \left(S_{i}\right)
$$

In cases where the index is equal to zero, there is a monopoly, meaning maximum concentration. The upper limit is equal to $\ln (n)$, and in this situation companies have equal market shares and the concentration is minimal.

In addition to the HHI' calculation, Resende (1994) also developed the adjusted entropy index (E') to solve intertemporal analyzes. E' varies between 0 (maximum concentration) and 1 (minimum concentration) (Equation 6).

$$
E^{\prime}=-\frac{1}{\ln (n)} \sum_{i==^{\prime}}^{n} S i \ln \left(S_{i}\right)
$$

FLORESTA, Curitiba, PR, v. 48, n. 4, p. 443-452, out/dez. 2018

Coelho Junior, L. M. et al.

ISSN eletrônico 1982-4688 
The Gini Coefficient (G) was proposed by Gini (1912). Originally developed to measure income inequality, it can also be used to measure the degree of inequality in country exports, since a high concentration implies high inequality (Equation 7).

$$
G=1-\frac{\left[\sum_{i=1}^{n}\left(S_{i j}+S_{i}\right)\right]}{n}
$$

In which: $s_{i j}$ : cumulative share of exports in ascending order.

The Gini coefficient varies between 0 (situation of zero inequality in the market) and 1 (absolute inequality). At the suggestion of Coelho Junior et al. (2010), the following classification was used to evaluate the results: 0 to 0.1 representing zero inequality; 0.101 to 0.250 representing zero to weak inequality; 0.251 to 0.500 representing weak to medium inequality; 0.501 to 0.700 representing average to strong inequality; 0.701 to 0.900 representing strong to very strong inequality; and 0.900 to 1.000 representing very strong to absolute inequality.

According to Bikker and Haaf (2002), the Hall and Tideman Index (HTI) introduces the $n$ elements in the indicator, meaning the share of each country receives a weight equal to its ranking in the construction of the index, and thus the emphasis is on the total number of countries in the industry (Equation 8).

$$
H T I=\left(2 \sum_{i=1}^{n} i S_{i}-1\right)^{-1}
$$

In which: $i$ : position occupied by the country in descending order.

The HTI interval ranges from 1 to $1 / \mathrm{n}$, with 1 being the high concentration, and $1 / \mathrm{n}$ not concentrated and in perfect equality.

As proposed by Horvarth (1970), the Comprehensive Concentration Index (CCI) measures both relative dispersion and absolute magnitude as a way to solve some deficiencies of the presented indicators. It represents the sum of the market share of the leading country with the sum of the squares of the proportional sizes of each country, weighted by a multiplier, which reflects the proportional size of the rest of the industry, as shown by the equation developed by Horvarth (1970) (Equation 9).

$$
C C I=S_{1}+\sum_{i=2}^{n} S_{i}^{2}\left(1+\left(1-S_{i}\right)\right)
$$

In which: $S_{1}$ : highest market share among the countries organized in descending order.

The index will be equal to 1 in case of monopoly, very high concentration.

\section{RESULTS}

Figure 1 shows the evolution of world pulp exports in trillions of US dollars (US $\$ 10^{9}$ ), from 1961 to 2014.

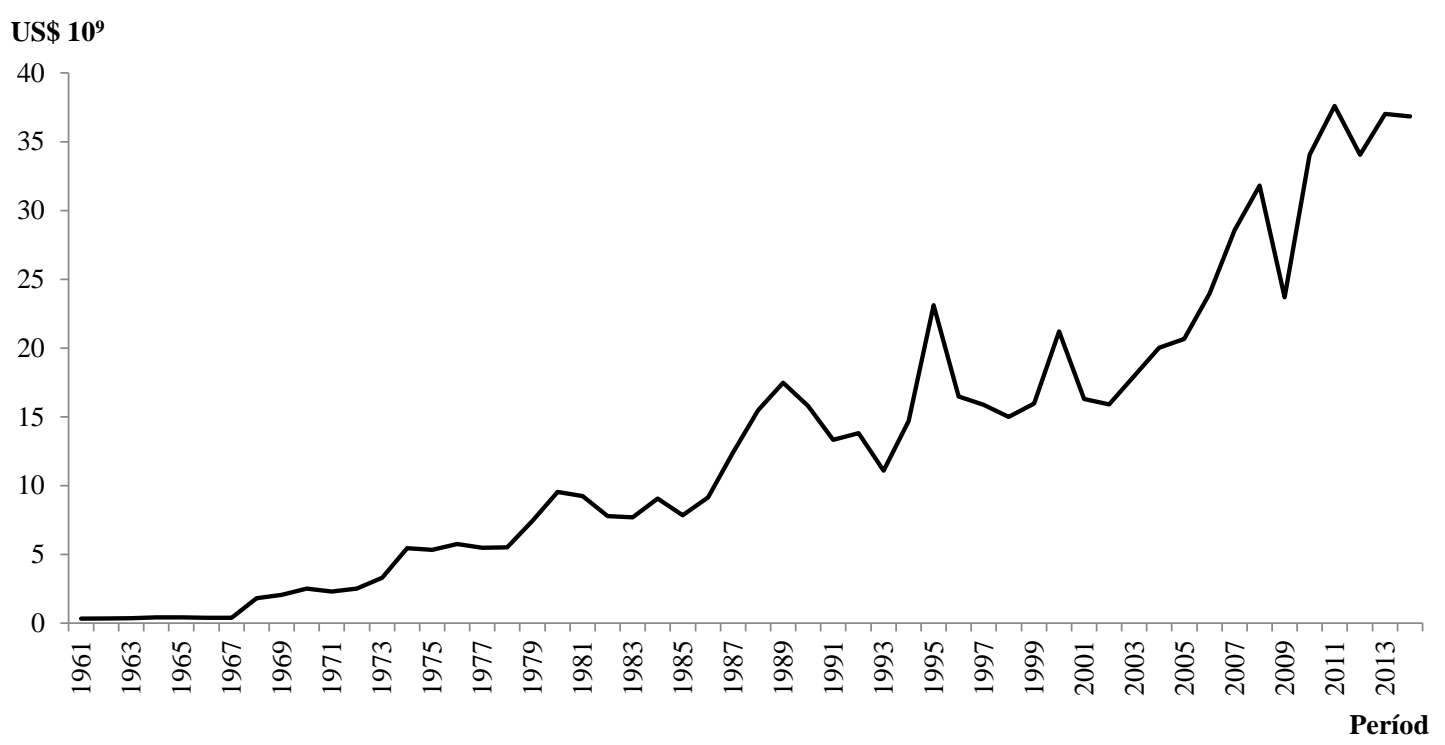

Source: FAO (2016) 
Figure 1. Evolution of global pulp exports in trillions of US dollars (US\$109), from 1961 to 2014.

Figura 1. Evolução das exportações mundiais de celulose em trilhões de dólares americanos (10 ${ }^{9}$ US $\left.\$\right)$, de 1961 a 2014.

Table 2 shows the evolution of world pulp export values for the ten largest countries in 2014 in trillions of US dollars (US $\$ 10^{9}$ ), and the quantity and top ten countries of the international pulp export ranking in the years of 1961, 1964, 1969, 1974, 1979, 1984, 1989, 1994, 1999, 2004, 2009 and 2014. Figure 2 shows the evolution of concentration indicators of world pulp exports from 1961 to 2014

Table 2. Evolution of world pulp export values for the 10 largest countries in 2014, in trillions of US dollars (US $\$ 10^{9}$ ). The quantity and top 10 countries in the international ranking of pulp exports in the years 1961, 1964, 1969, 1974, 1979, 1984, 1989, 1994, 1999, 2004, 2009, and 2014.

Tabela 2. Evolução dos valores das exportações de celulose no mundo para os dez maiores países em 2014, em trilhões de dólares americanos ( $10^{9}$ US\$), e a quantidade e o top dez países do ranking internacional de exportação de celulose nos anos de 1961, 1964, 1969, 1974, 1979, 1984, 1989, 1994, 1999, 2004, 2009 e 2014.

\begin{tabular}{|c|c|c|c|c|c|c|c|c|c|c|c|c|}
\hline & 1961 & 1964 & 1969 & 1974 & 1979 & 1984 & 1989 & 1994 & 1999 & 2004 & 2009 & 2014 \\
\hline Canada & 0.065 & 0.084 & 0.697 & 1.861 & 2.622 & 3.019 & 5.862 & 4.945 & 5.018 & 5.485 & 4.465 & 6.532 \\
\hline United States & 0.075 & 0.094 & 0.281 & 0.821 & 1.093 & 1.483 & 3.521 & 2.833 & 2.601 & 2.868 & 4.030 & 5.806 \\
\hline Brazil & 0.00003 & 0.0002 & 0.003 & 0.037 & 0.181 & 0.396 & 0.684 & 0.855 & 1.241 & 1.722 & 3.309 & 5.291 \\
\hline Sweden & 0.089 & 0.095 & 0.469 & 1.295 & 1.336 & 1.348 & 2.040 & 1.313 & 1.343 & 1.991 & 1.953 & 2.646 \\
\hline Chile & - & - & 0.015 & 0.078 & 0.167 & 0.200 & 0.333 & 0.718 & 0.767 & 1.211 & 1.975 & 2.603 \\
\hline Finland & 0.039 & 0.051 & 0.257 & 0.348 & 0.707 & 0.684 & 1.210 & 0.843 & 0.806 & 1.173 & 0.780 & 2.121 \\
\hline Indonesia & - & - & - & - & - & - & 0.046 & 0.069 & 0.488 & 0.590 & 0.867 & 1.719 \\
\hline The Netherlands & - & - & 0.001 & 0.002 & 0.003 & 0.0004 & 0.003 & 0.081 & 0.187 & 0.249 & 0.868 & 1.189 \\
\hline Russia & - & - & - & - & - & - & - & 0.354 & 0.370 & 0.703 & 0.698 & 1.122 \\
\hline Germany & 0.005 & 0.005 & 0.014 & 0.032 & 0.059 & 0.067 & 0.140 & 0.126 & 0.174 & 0.332 & 0.601 & 0.937 \\
\hline Rest of the world & 0.069 & 0.077 & 0.332 & 0.982 & 1.275 & 1.861 & 3.634 & 2.542 & 2.955 & 3.690 & 4.685 & 7.021 \\
\hline The world & 0.342 & 0.407 & 2.069 & 5.456 & 7.442 & 9.059 & 17.472 & 14.679 & 15.950 & 20.014 & 24.231 & 36.278 \\
\hline Ranking & 20 & 18 & 33 & 36 & 34 & 34 & 36 & 58 & 67 & 93 & 110 & 118 \\
\hline $1 \mathrm{st}$ & SWE & SWE & CAN & $\mathrm{CAN}$ & CAN & CAN & CAN & $\mathrm{CAN}$ & CAN & CAN & $\mathrm{CAN}$ & $\mathrm{CAN}$ \\
\hline 2nd & USA & USA & SWE & SWE & SWE & USA & USA & USA & USA & USA & USA & USA \\
\hline $3 \mathrm{rd}$ & CAN & $\mathrm{CAN}$ & USA & USA & USA & SWE & SWE & SWE & SWE & SWE & BRA & BRA \\
\hline 4th & NOR & NOR & FIN & FIN & FIN & FIN & FIN & BRA & BRA & BRA & $\mathrm{CHI}$ & SWE \\
\hline 5 th & FIN & FIN & NOR & NOR & USSR & USSR & POR & FIN & FIN & $\mathrm{CHI}$ & SWE & $\mathrm{CHI}$ \\
\hline 6th & RSA & RSA & USSR & JPN & NOR & BRA & BRA & $\mathrm{CHI}$ & $\mathrm{CHI}$ & FIN & INA & FIN \\
\hline 7 th & GER & GER & POR & USSR & BRA & POR & USSR & POR & POR & RUS & FIN & INA \\
\hline 8th & YUG & YUG & RSA & POR & $\mathrm{CHI}$ & NOR & NOR & RUS & INA & INA & RUS & NET \\
\hline 9th & JPN & DEN & FRA & $\mathrm{CHI}$ & POR & $\mathrm{CHI}$ & $\mathrm{CHI}$ & SPA & RUS & SPA & GER & RUS \\
\hline 10th & CZEC & CZEC & AUT & RSA & RSA & RSA & SPA & NOR & RSA & POR & BEL & GER \\
\hline
\end{tabular}

In which: AUT: Austria; BEL: Belgium; BRA: Brazil; CAN: Canada; CHI: Chile; CZEC: Czechoslovakia; DEN: Denmark; SPA: Spain; FIN: Finland; FRA: France; GER: Germany; INA: Indonesia; JPN: Japan; NET: The Netherlands; NOR: Norway; POR: Portugal; RSA: South Africa; RUS: Russia; SWE: Sweden; USA: The United States; USSR: The Soviet Union; YUG: Yugoslavia.

\section{DISCUSSION}

According to Figure 1, the value of world pulp exports was US\$342 billion in 1961 to US\$36.84 trillion in 2014 , presenting an average annual growth of $9.23 \%$ p.a. This increase in pulp exports is linked to greater demand for paper and is associated with the economic development of nations. According to Rezende et al. (2008), the greater the per capita consumption of paper, the more developed a country is.

Despite the growth trend in the study period, some oscillations were observed in certain periods, which may have been caused by the effects of crises and wars in the international scenario, especially in the pulp exporting countries. The Cold War ended (1989) with the dissolution of the Soviet Union between 1989 and 1993 , which had ranked $7^{\text {th }}$ among the largest pulp exporters (Table 2), and then the reorganization of the Commonwealth of Independent States (CIS) in 1991. Pulp exports around the world were subsequently affected by this. In 1994, the restructuring of the Brazilian economy from the Real plan contributed to an increase in Brazilian pulp exports. Coelho Junior et al. (2008) show that several crises occurred which directly affected international trade, and consequently the forestry sector.

Pulp exports fluctuated significantly in the period from 1995 to 1999 due to the domino effect of the Mexican (1995), Russian (1998) and Brazilian (1999) crises. The terrorist attack on the United States in September 2001 reflected a drop in exports in 2002. From 2002, the international economy was growing until 2008, with the

FLORESTA, Curitiba, PR, v. 48, n. 4, p. 443-452, out/dez. 2018

Coelho Junior, L. M. et al.

ISSN eletrônico 1982-4688

DOI: $10.5380 /$ rf.v48i4.48334 
US crisis showing its effects in 2009 going from US $\$ 31.81 \times 10^{9}$ to US $\$ 23.69 \times 10^{9}$, respectively. This reduction in exports was a consequence of the commercial relations that reduced its pulp imports, affecting pulp production
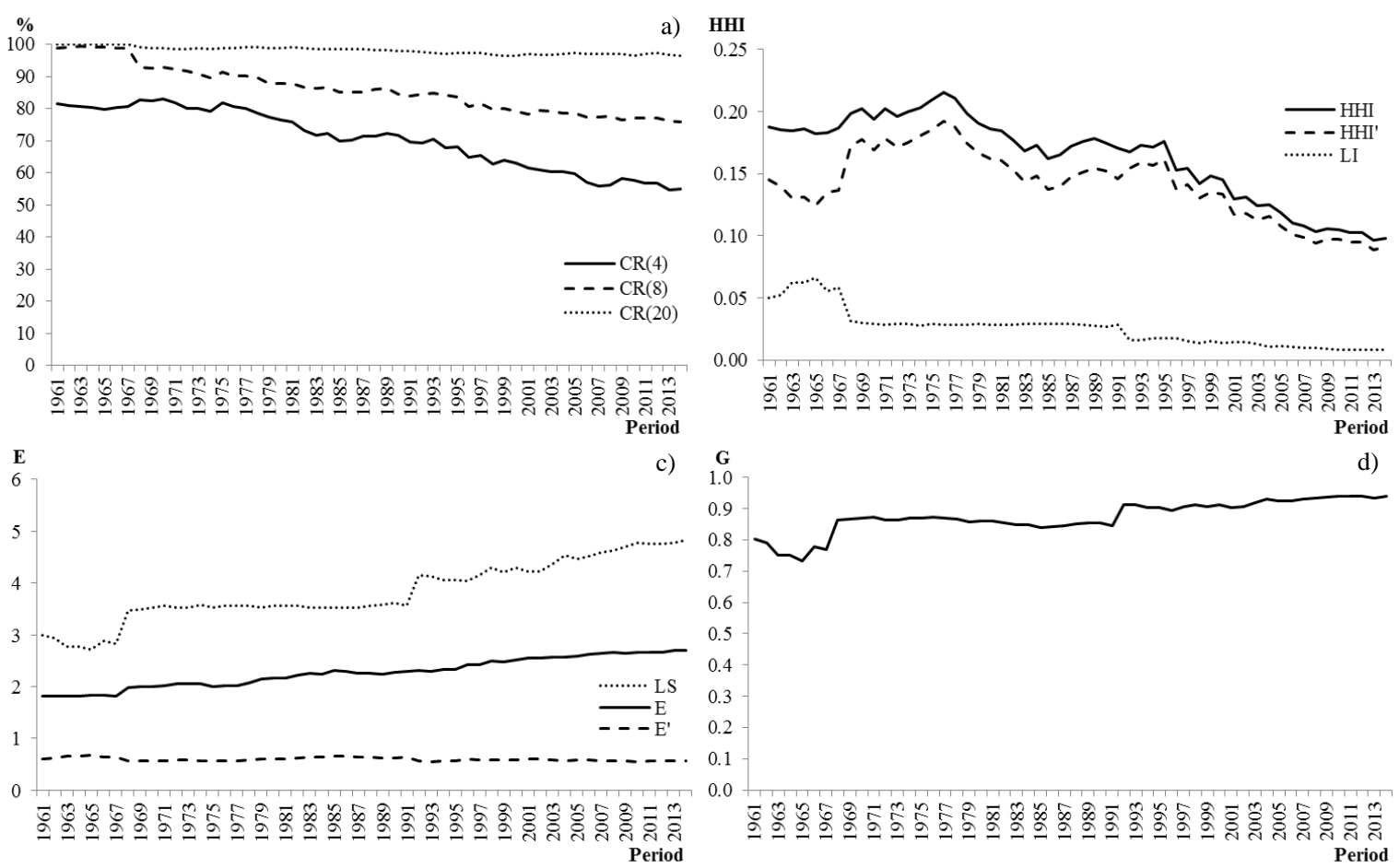

c)
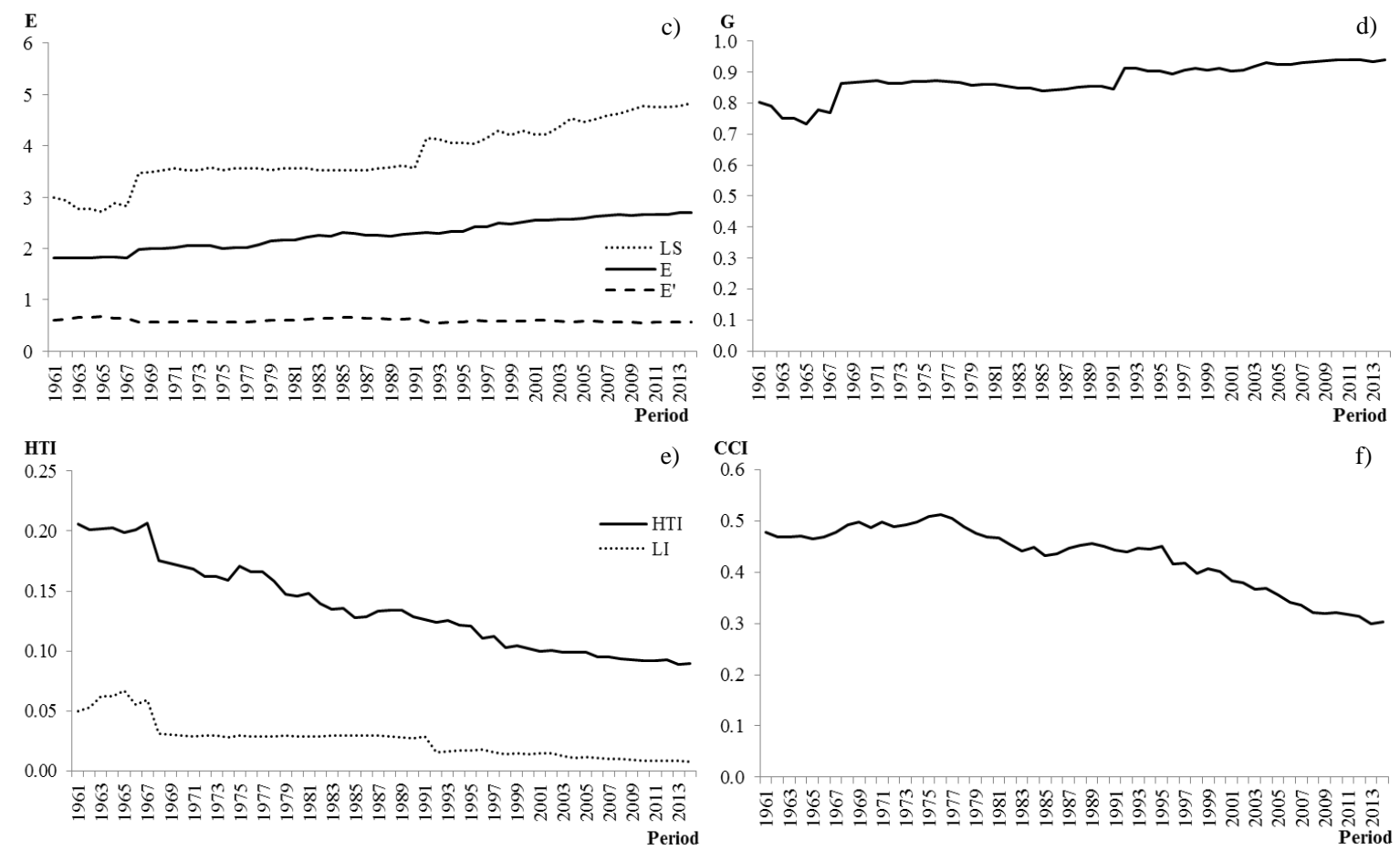

in the world as a whole.

Figure 2. Evolution of the concentration indicators of world pulp exports from 1961 to 2014. Concentration ratio of the four [CR(4)], eight [CR(8)] and twenty [CR (20)] largest pulp exporters (2a); Herfindahl-Hirschman Index (HHI), Lower Limit (LI) and Adjusted Herfindahl-Hirschman Index (HHI') (2b); Theil Entropy Index (E), Upper Limit (LS) and Adjusted Theil Entropy (E') (2c); Gini index (G) (2d); Hall and Tideman Index (HTI) and Lower Limit (LI) (2e); Comprehensive Concentration Index (CCI) (2f).

Figura 2. Evolução dos indicadores de concentração de exportação mundiais de celulose, no período de 1961 a 2014: Razão de Concentração dos quatro [CR(4)], oito [CR(8)] e vinte [CR(20)] maiores exportadores celulose (2a); Índice de Herfindahl-Hirschman (HHI), Limite Inferior (LI) e Índice de HerfindahlHirschman ajustado (HHI') (2b); Índice de Entropia de Theil (E), Limite Superior (LS) e Entropia de Theil ajustado (E’) (2c); Índice de Gini (G) (2d); Índice de Hall e Tideman (HTI) e Limite Inferior (LI) (2e); e Índice de Concentração Compeensiva (CCI) (2f).

According to Table 2, Canada, the United States and Sweden occupied the main positions in the world ranking of pulp exports in the period from 1961 to 2014. From 1961 to 1967 there was a fierce dispute over the leadership of pulp exports by the United States and Sweden, and Canada was third in the world ranking. Since 1968, Canada has taken over the hegemony of world pulp exports. In 1968, the value of pulp exports was US $\$ 581 \times 10^{6}$, and in 2014 it reached US\$ $6.53 \times 10^{9}$, with average annual growth of $5.4 \%$. The United States was 
in $2^{\text {nd }}$ place in exports for almost the entire period, with an exception between 1968 and 1979 when Sweden was the $2^{\text {nd }}$ largest exporter. US exports went from US $\$ 254 \times 10^{6}$ in 1968 to US $\$ 5.81 \times 10^{9}$ in 2014 , reaching an average growth of $7.03 \%$ p.a.

Table 2 indicates that Brazilian exports in the 1960s and 1970s were modest when compared to the exports in the decades of the $21^{\text {st }}$ century. The beginning of government programs with fiscal incentives for reforestation, in 1965, coupled with favorable edaphoclimatic conditions led to conditions for expanding pulp production in Brazil directed to exports. Brazilian exports on the world stage reached their maturity in the 1980s, when their international ranking fluctuated between $5^{\text {th }}$ and $7^{\text {th }}$ position, going from US\$364 $\times 10^{6}$ in 1980 to US\$595 $\times 10^{6}$ in 1990. From 1990, domestic industry consolidated and exports reached an average growth of $9.52 \%$ p.a. until it reached the position of $3^{\text {rd }}$ largest exporter of pulp in the world in 2014 , with US $\$ 5.29 \times 10^{6}$.

This Brazilian achievement in the gains of pulp exports came from the national development of forest sciences and the maturity of the pulp industry reached in the 1980s and consolidated in the 1990s. Hilgenberg and Bacha (2001) stated that the industry was already operating with equipment which was compatible with global technology and was integrated into the forest base. At that time, the country was already self-sufficient in the production of planted forest and perfectly adapted to environmental pressure.

Table 2 also shows that there was an expansion in the number of pulp exporting countries, which began with 20 countries in 1961 and reached 118 countries in 2014. In 1989, there were 36 exporting countries; in 1995 , it rose to 58; in the year 2000, there were already 73 countries; and in 2008 it reached a total of 103 exporting countries. This, however, does not mean that export growth occurred due to an expansion of exporters in the international pulp scenario, as can be seen in Figure 2A, since about $100 \%$ of exports were dominated by the 20 largest pulp exporters in the world in the studied period.

In Figure 2, the indicators showed evolution and indicated deconcentrating trends in the world pulp exports from 1961 to 2012. Coelho Junior et al. (2013) also found that there was a reduction in the global concentration of forest product exports. Figure 2A shows that there were trends in the world's concentration of very high to moderately high pulp exports in the analyzed period when considering the four [CR(4)] and eight [CR(8)] major pulp exporting countries. Scherer and Ross (1990) argue that when the four largest exporting countries own more than $40 \%$ of international trade, it is inferred that the market structure is oligopolistic. Therefore, as shown in Figure 2A, it is considered that the entire studied period has an oligopolistic market structure for world pulp exports.

In 1961, exports were controlled by only 20 countries, and among them the four largest shares [(Sweden (25.92\%), United States (22.02\%), Canada (19.04\%) and Norway 56\%)] accounted for more than $80 \%$ of exports, classifying CR(4) as a very high concentration. In 1981, 35 countries exported pulp in the world, and the CR(4) was $75.71 \%$, with a decrease in concentration. However, this index continued to be classified as a very high concentration in world pulp exports. The countries included in the CR(4) of 1981 were Canada (34.46\%), the United States (17.91\%), Sweden (14.46\%) and Finland $(8.88 \%)$ instead of Norway. In 2001, the number of exporting countries practically doubled to 68 , and the CR(4) was $61.64 \%$ (moderately high), represented by Canada (28.63\%), the United States (16.14\%), Sweden (9.21\%) and Brazil (7.67\%). In 2014, the number of exporters reached 125 countries, but the concentration remained moderately high for the CR(4) (55.02\%), with the shares of Canada (17.73\%), the United States (15.76\%), Brazil (14.36\%) and Sweden (7.17\%).

From 1961 to 1967 , the $\mathrm{CR}(8)$ remained above $98 \%$, being classified as a very high concentration, and the number of exporting countries fluctuated between 16 and 20. In the following years from 1968 to 1977 , the indices decreased due to an increase in significant share by the 20 largest producers, and the number of participating countries ranged from 32 to 36 . However, the CR(8) presented values higher than $90 \%$ (very high concentration). From 1978 to $1997, \mathrm{CR}(8)$ had a high concentration $(89.50 \%)$ to moderately high $(81.39 \%)$. In the period from 1998 to 2014, CR(8) remained moderately high. According to Bain (1958), it was found that the world pulp exports present an oligopolistic market structure with a competitive extremity. In the period from 1961 to 2014, the CR(20) behavior shows that the 20 largest pulp exporters make up almost $100 \%$ of world exports, even with the introduction of new countries in international pulp trade.

It is observed in Figure 2B that HHI values tended to approach their lower limits throughout the analysis period. As the HHI' also decreased, deconcentrating tendencies of the studied series were demonstrated, corroborating the inferences made by the Concentration Ratio $[\mathrm{CR}(\mathrm{k})]$. The distance between HHI and LL shows the effect of the concentration in the analyzed periods. From 1961 to 1967, a non-concentrated market structure was diagnosed. The following period, from 1968 to 1976, showed tendencies to increase in concentration and reached the maximum index in 1976. After that year, there was evidence that the index values suffered reductions with small oscillations until 2014.

The mean HHI' for the study period was 0.1409 , indicating a non-concentrated market. There was also a reduction in the concentration of exports for the adjusted index. Between the years 1961 and 1967, HHI' values

FLORESTA, Curitiba, PR, v. 48, n. 4, p. 443-452, out/dez. 2018

Coelho Junior, L. M. et al.

ISSN eletrônico 1982-4688

DOI: $10.5380 /$ rf.v48i4.48334 
showed that the market behaved as non-concentrated (0.1450 and 0.1368 , respectively). From 1968 to 1982 the HHI' ranged from 0.1173 to 0.1529 , and peaked in 1976 with 0.1923 . The concentration during this period was moderate. However, from 1983 to 2014 the HHI' tended to decrease, going from 0.1434 to 0.0907 , and the concentration was weak, with the exception of the period from 1988 to 1995, when HHI' varied frequently and was characterized as moderate in some years.

Figure 2C shows the distance from the Theil Entropy Index (E) and Upper Limit (UL), and shows that the concentration of the world's pulp exports decreases from the distance of these two curves (E/UL) in the period from 1961 to 2014, corroborating the analyzes for HHI. From 1961 to 1964, E/UL had small oscillations due to a reduction in the number of pulp exporters from 20 countries in 1961 to 16 in 1964. From that period, E/UL went from 1.1783 in 1961 to 0.9572 in 1964, while E' dropped from 0.6067 in 1968 to 0.6548 in 1964 . The year 1965 had the highest adjusted index (0.6745) and also the highest E/UL (0.8815), meaning that the concentration was lower in that year.

According to Figure 2D, there was strong absolute inequality in world pulp exports between 1961 and 2014 according to the Gini Coefficient. Although some reductions in inequality occurred during the period, there was a tendency for inequality to increase. The greatest inequality was 0.9413 in 2010, being considered very strong to absolute, and the lowest reached 0.7326 in 1965 , classified as strong to very strong. This is also in agreement with the lower concentration values of $\mathrm{E}$.

The increase in the number of exporting countries, and above all, the emergence of countries after the dissolution of the Soviet Union did not guarantee a reduction of inequality. In fact, there was an increase of inequality in the studied period. The Gini coefficient dropped from 0.8036 in 1961 to 0.9388 in 2014 . Many countries still did not have strong market competitiveness, thus increasing inequality throughout the study period.

According to the Gini coefficient, the inequality during the study period can be classified as strong to absolute. In the first 30 years, the Gini coefficient dropped from 0.8036 in 1961 to 0.8441 in 1991 , and inequality was classified as strong to very strong. In the next period (from 1992 to 1995) the inequality went from very strong to absolute, while the Gini coefficient fell from 0.9120 to 0.9027 . In 1996, the inequality returned to be classified as strong to very strong, with Gini coefficient equal to 0.8947. In recent years (1997 to 2014) with a significant increase in the number of countries, inequality was classified as very strong to absolute, and there was also an increase in the Gini coefficient from 0.9070 to 0.9388 between 1997 and 2014.

In Figure $2 \mathrm{~F}$, a reduction trend in the concentration of pulp exports can be observed by analyzing the concentration behavior from the difference between the Hall and Tideman Index and the Lower Limit (HTI/LL). In the first period from 1961 to 1967, the HTI/LL presented oscillations, but there was a decrease at the end, going from 0.159 in 1961 to 0.1444 in 1967 . In general, HTI/LL suffered many fluctuations from 1968 to 2001, but tended to fall, from 0.1438 to 0.0854 . In the last period from 2002 to 2014 , the HHI/LL remained stable to the various changes that occurred. It reached its lowest point in $2013(0.0806)$.

In observing Figure $2 \mathrm{~F}$ which shows the Comprehensive Concentration Index (CCI), reducing trends of world pulp export concentration may be observed in the analyzed period. It is noteworthy that there was a decline in the share of the largest exporting country in the international scenario over time. In 1961, the CCI was 0.4781, reaching the highest value of the time series in 1976 (0.5122). The CCI experienced small swings from 1977 to 2014, with a downward trend from 0.5059 in 1977 to the lowest value in the period under review, being 0.2997 in 2014.

\section{CONCLUSION}

- There was a tendency for world pulp exports to grow during the analyzed period, driven by increasing demand driven by population growth and per capita consumption, encouraging an increase in the number of exporting countries.

- The CR (k) of the world pulp exporting countries showed that the four largest [CR(4)] and eight largest $[\mathrm{CR}(8)]$ countries had a high concentration, oligopolistic market structure with a competitive extremity, and almost $100 \%$ of exports are under the dominance of the 20 largest countries [CR(20)].

- Analysis of the HHI, E, HTI and CCI indicators suggest that there is a concentration in world pulp exports, although there has been a deconcentrating tendency.

- Despite the increase in the number of exporting countries, there was no significant reduction in the inequality of world pulp exports.

- According to the Gini coefficient, the inequality was strong to absolute. 


\section{REFERENCES}

BAIN, J. S. Pricing, distribution and employment. New York: Holt Rinehart and Winston, 1958.

BAIN, J. Industrial organization. New York: John Wiley and Sons, 1959. 274p.

BIKKER, J.A.; HAAF, K. Competition, concentration and their relationship: an empirical analysis of the banking industry, Journal of Banking \& Finance, V. 26, p. 2191-2214, 2002.

COELHO JUNIOR, L. M.; REZENDE, J. L. P.; BORGES, L. A. C. Influência dos planos econômicos e análise comparativa dos preços do carvão vegetal e do petróleo. In: Simpósio latino-americano sobre manejo florestal, 2008, Santa Maria - RS. Anais... Santa Maria - RS: UFSM, 2008. v. 4. p. 159-164.

COELHO JUNIOR, L. M.; REZENDE, J. L. P.; ÁVILA, E. S.; OLIVEIRA, A. D.; BORGES, L. A. C. Analysis of the Brazilian celulose industry concentration (1998 a 2007). Cerne, Lavras, v.16, n.2, abr.-jun. 2010.

COELHO JUNIOR, L. M.; REZENDE, J. L. P.; OLIVEIRA, A. D. Concentração das exportações mundiais de produtos florestais. Ciência Florestal, Santa Maria, v. 23, n. 4, p. 691-701, out.-dez., 2013.

CUENCA, M. A. G.; DOMPIERI, M. H. G. Dinâmica espacial da canavicultura e análise dos efeitos sobre o valor bruto da produção, na região dos tabuleiros costeiros da Paraíba, Pernambuco e Alagoas. Revista Econômica do Nordeste, v. 47, n. 4, p. 91-106, 2017. Disponível em: 〈https://ren.emnuvens.com.br/ren/article/view/620/497〉. Acesso em: 15/12/2017

FOOD AND AGRICULTURE ORGANIZATION OF THE UNITED NATIONS - FAO. FAO Statistics Division. Rome, 2013. Disponível em: 〈http://faostat3.fao.org/faostat-gateway/go/to/download/F/*/E〉. Acesso em: 15 de dez. 2013.

GINI, C. Variabilità e mutabilità. 1912. Reprinted in Memorie di metodológica statistica. Rome, Libreria Eredi Virgilio Veschi, 1955.

HILGEMBERG, E. M.; BACHA, C. J. C. A evolução da indústria brasileira de celulose e sua atuação no mercado mundial. Revista Análise Econômica, Porto Alegre, v. 19, n. 36, p.145-164, 2001.

HIRSCHMAN, A. O. The paternity of an index. The American Economic Review, Pittsburgh, v. 54, n. 5, p 761762, Sept. 1964.

HORVARTH, J. Suggestion for a Comprehensive Measure of Concentration. Southern Economic journal, 36, 446-452, 1970.

INDÚSTRIA BRASILEIRA DE ÁRVORES - IBÁ, 2014. Disponível em: <http://www.iba.org/shared/iba_2014_pt.pdf>. Acesso em 09 de mar. 2015.

MONTEBELLO, A. E. S.; BACHA, C. J. C. Impactos da reestruturação do setor de celulose e papel no Brasil sobre o desempenho de suas indústrias. Estudos Econômicos, São Paulo, SP, v. 43 n. 1, p. 109-137, jan./mar. 2013

NOCE, R.; SILVA, M. L.; SOUZA, A. L.; SIlVA, O. M.; MENDES, L. M.; CARVALHO, R. M. M. A. I; VALVERDE, S. R. Competitividade do Brasil no mercado internacional de aglomerado. Revista Árvore, Viçosa, MG, v. 32, n. 2, p. 245-250, mar./abr. 2008.

NOCE, R.; CARVALHO, R. M. M. A.; CANTO, J. L.; SILVA, M. L.; MENDES, L. M. Medida da desigualdade do mercado internacional de compensado. Cerne, v. 13, n. 1, p. 107-110, jan./mar. 2007.

POSSAS, M. L. Estruturas de mercado em oligopólio: economia e planejamento. 2. ed. São Paulo: Hucitec, 1999. $191 \mathrm{p}$.

RESENDE, M. \& BOFF, H. Concentração industrial. In: KUPFER, D. \& HASENCLEVER, L. (Org.). Economia industrial: Fundamentos teóricos e práticas no Brasil. Rio de Janeiro: Campus, 2002. p. 73-90.

RESENDE, M. Medidas de concentração industrial: uma resenha. Revista Análise Econômica, Porto Alegre, v.12, n.21, p. 24-33, mar./set. 1994.

REZENDE, J. L. P.; COELHO JUNIOR, L. M.; OLIVEIRA, A. D.; SILVA, M. L. Economical plans effects on charcoal prices. CERNE (Lavras), v. 13, p. 188-199, 2007.

FLORESTA, Curitiba, PR, v. 48, n. 4, p. 443-452, out/dez. 2018

Coelho Junior, L. M. et al.

ISSN eletrônico 1982-4688

DOI: $10.5380 /$ rf.v48i4.48334 
REZENDE, J. L. P.; COELHO JUNIOR, L. M.; BORGES, L. A. C. Madeira e derivados: oportunidades do Brasil no mercado internacional. In: OLIVEIRA, J. T. S.; FIEDLER, N. C.; NOGUEIRA, M. (Ed.) Tecnologias aplicadas ao setor madeireiro III. Jerônimo Monteiro: Suprema, 2008. P. 11-42.

SCHETTINI, B. L. S.; SILVA, M. L.; JACOVINE, L. A. G.; ALVES, E. B. B. M.; VILlANOVA, P. H. Avaliação da concentração do mercado mundial de pellets de madeira e as oportunidades para o Brasil. Enciclopédia Biosfera, v. 13, p. 103-113, 2016.

SCHERER, F. M.; ROSS, D. Industrial market structure and economic performance. 3. ed. Boston: Houghton Mifflin, 1990. $270 \mathrm{p}$.

SOARES, N. S.; SILVA, M. L. Oferta de exportação da celulose brasileira. Revista de Política Agrícola, Brasília, v. 20, n. 2, p. 52-65. Abr-Maio-Jun. 2011.

SOARES, P. R. C; CARDOSO, M. V.; ALMEIDA, A. N.; SILVA, J. C. G. L.; TIMOFEICZYK JUNIOR, R.; ANGELO, H. Concentração e desigualdade nas importações norte-americanas de celulose. Scientia Forestalis, Piracicaba, v. 42, n. 102, p. 173-179, jun. 2014. 